\title{
Determinants of adaptation choices
} to climate change by sheep and goat farmers in Northern Ethiopia: the case of Southern and Central Tigray, Ethiopia

\author{
Fikeremaryam Birara Feleke ${ }^{1 *}$, Melaku Berhe ${ }^{1}$, Getachew Gebru² and Dana Hoag ${ }^{3}$
}

${ }^{*}$ Correspondence:

fbirara291@yahoo.com

${ }^{1}$ Department of Natural

Resource Economics

and Management, College

of Dryland Agriculture

and Natural Resource,

Mekelle University, P.O.

Box 231, Mekelle, Ethiopia

Full list of author information

is available at the end of the

article

\begin{abstract}
The livestock sector serves as a foremost source of revenue for rural people, particularly in many developing countries. Among the livestock species, sheep and goats are the main source of livelihood for rural people in Ethiopia; they can quickly multiply, resilient and are easily convertible to cash to meet financial needs of the rural producers. The multiple contributions of sheep and goat and other livestock to rural farmers are however being challenged by climate change and variability. Farmers are responding to the impacts of climate change by adopting different mechanisms, where choices are largely dependent on many factors. This study, therefore, aims to analyze the determinants of choices of adaptation practices to climate change that causes scarcity of feed, heat stress, shortage of water and pasture on sheep and goat production. The study used 318 sample households drawn from potential livestock producing districts representing 3 agro-ecological settings. Data was analyzed using simple descriptive statistical tools, a multivariate probit model and Ordinary Least Squares (OLS). Most of the respondents (98.6\%) noted that climate is changing. Respondents' perception is that climate change is expressed through increased temperature (88\%) and decline in rainfall (73\%) over the last 10 years. The most commonly used adaptation strategy was marketing during forage shock ( $96.5 \%)$, followed by home feeding ( $89.6 \%)$. The estimation from the multivariate probit model showed that access to information, farming experience, number of households in one village, distance to main market, income of household, and agro-ecological settings influenced farmers' adaptation choices to climate change. Furthermore, OLS revealed that the adaptation strategies had positive influence on the household income.
\end{abstract}

Keywords: Sheep, Goat, Climate change, Adaptation, Choice, Determinants, Agroecological settings

\section{Background}

Climate change is a global phenomenon that results in global warming, droughts, flooding and depletion of natural resources (Adger et al. 2003; Parry et al. 2004; Naqvi and Sejian 2011). A study by Nelson et al. (2009) indicated that climate change is expected to bring about significant yield losses between 3 and $30 \%$ and extinction of land plants and animal species between 15 and $37 \%$ by 2050 unless remedial measures are taken into 
consideration. Developing countries are highly vulnerable to climate change since their economy predominantly relies on rain-fed agriculture that totally depends on natural factors. Traditional farming systems practiced, which have low technological capacity, cannot help to adapt and mitigate drastic climate change (Tubiello 2012).

Being a developing country, Ethiopia's agriculture contributes about $42-45 \%$ to its gross domestic product, employs more than $80 \%$ of the population and generates more than $85 \%$ of foreign exchange earnings (Deressa 2007; Gebreegziabher et al. 2011; You and Ringler 2011). By 2020 in Ethiopia, however, yields from agriculture could fall by $50 \%$ because of the adverse effects of climate change like rise in temperature, drought, flood, erratic rainfall and others (FDRE 2011). Climate change has been recognized as having potentially severe impacts on livelihood and development (Mengestu 2011). Tigray is one of the nine Regional States in Ethiopia that is being affected by recurrent drought because of both its arid and semi arid nature (Deressa et al. 2008). Consequently, the impacts of climate change and variability remain a serious challenge.

Despite the occurrences of persistent droughts and agriculture failure emanated from climate change in the Tigray region, livestock provides multiple economic and social benefits. Particularly, sheep and goats are easily convertible to cash to meet households' financial problems such as school fees and agricultural inputs from the sales of live animals and their byproducts (meat, egg, manure etc.). As a result, sheep and goats are considered as assets (as a form of insurance) that require minimum initial investment with quick returns due to fast multiplication (Ayele et al. 2008; Legesse et al. 2008; Amankwah et al. 2012; Musara et al. 2013; Hailu 2014).

Although the benefits from sheep and goats hold great promise, the current level of its contribution to supporting rural livelihoods is low due to climate change related factors. Thermal, nutritional, and water related stresses, and restlessness are some of the consequences of climate change related factors that affect sheep and goat productivity (AL-Haidary 2004; Sevi et al. 2007; Alam et al. 2011; Kandemir et al. 2013; Sejian 2013). Increased incidence of disease and parasitic infection, decreasing trend of feed and fodder resources, low productive and reproductive performance are some of the consequences mainly related to the negative effects of climate change (Henry et al. 2012; Singh et al. 2012). Among the livestock species, sheep and goats are more vulnerable due to their heavily reliance on climate sensitive resources and immobility during flood (Oseni and Bebe 2010), and may not adapt to extreme climate change phenomena such as shortage of fodder, floods and droughts (Tologbonse et al. 2011; Sahoo et al. 2013; Taruvinga et al. 2013). As sheep and goats are owned by the poor section of the rural community who are living in dire poverty, any intervention that improves the productivity of sheep and goats could have positive contribution in reducing the existing poverty in the area.

Adaptation therefore remains one of the policy options to address climatic challenges prevailed on the livestock sector such as on sheep and goats (Deressa et al. 2008; Di Faclo et al. 2011). This has great relevance for developing countries seeking to maintain food security if it is focused to go hand-in-hand with the long-term policy priority among poor farmers (Di Faclo et al. 2011; Tubiello 2012). Their decision to adapt to climate change depends on socio-economic and environmental factors (Taruvinga et al. 2013). Obviously, farmers with the low capacity to adapt are generally the most 
vulnerable to the negative impacts of climate variability and change. Within the spectrum of livestock versus adaptation methods to climatic change, many researchers have identified important adaptation strategies (Dick et al. 2008; Henry et al. 2012; Singh et al. 2012). Despite significant progress, many questions regarding the prospects for ruminant animals mainly of sheep and goats have yet to be recognized (Panin 2000; Legesse et al. 2008). Some studies (Dick et al. 2008; Tologbonse et al. 2011) indicate that different adaptation methods to climate change are applied by sheep and goats farmers at different agro-ecological zones, but these studies failed to identify the determinants of each adaptation method used by each farmer located at each agro-ecological zone. This study, therefore, seeks to analyze the determinants of choices of adaptation strategies to climate change by sheep and goat farmers in the Southern and Central Tigray Zones, North Ethiopia.

\section{Methods}

\section{Description of the study area}

This study was carried out in three districts (Kolla-Tembein, Alaje and Ofla) located in the Tigray Regional State, Northern Ethiopia. Kolla-Temben is situated in Central Tigray zone; Alaje and Ofla are in Southern Tigray zone. The Kolla-Temben, Alaje and Ofla districts represent lowland, midland and highland agro-ecological settings, respectively. Geographically, the Southern Tigray zone is located at $12^{\circ} 57^{\prime} 37.2^{\prime \prime}\left(12.9603^{\circ}\right) \mathrm{N}$ latitude and $39^{\circ} 31^{\prime} 41.9^{\prime \prime}\left(39.5283^{\circ}\right)$ E longitudes with average elevation of 2664 meters above sea level. Whereas the Central Tigray zone is located at $13^{\circ} 47^{\prime} 6^{\prime \prime}\left(13.78507^{\circ}\right) \mathrm{N}$ latitude and $38^{\circ} 49^{\prime} 14^{\prime \prime}\left(38.82054^{\circ}\right)$ E longitude with average elevation of $1197 \mathrm{~m}$ above sea level.

\section{Sampling procedure}

Purposive sampling method was employed to select three districts namely Kolla-Tembien, Alaje and Ofla; which represents low land, mid land and high land agro-ecological setting respectively. The districts selected have potential for small ruminant farming and sheep and goats have been inhabited in these districts since long ago.

A representative sample size was estimated at $95 \%$ confidence level and below $1 \%$ error commitment, as shown below (Chand et al. 2012):

$$
n=\frac{N Z^{2} P(1-P)}{N \cdot e+Z^{2} P(1-P)}
$$

where $\mathrm{n}=$ is the sample size, $\mathrm{N}=$ is the population size, $\mathrm{Z}=$ Confidence level at $95 \%$, $\mathrm{Z}=1.96, \mathrm{P}=$ Estimated population proportion (0.5), $\mathrm{e}=$ is the precision level (0.003).

Based on the sampling estimation made 318 sample households were selected out of the total 72,326 households. Again, out of 318 sample households; 118, 89 and 111 households were drawn from Kolla-tembein, Alaje and Ofla district, respectively. Sample size drawn from each district is proportional to targeted household population in each respective district as shown in Table 1.

Households those having either sheep and/or goat herd obtained from the administrative office of each district was used as a sampling frame. The final sample households were selected from the sampling frame using systematic random sampling technique. 
Table 1 Sample size distribution by districts and agro-ecological zone

\begin{tabular}{lllc}
\hline Districts & Agro-ecological zone & Target household population $^{\text {a }}$ & Sample size \\
\hline Kolla-Tembien & Lowland & 26,867 & 118 \\
Alaje & Midland & 20,081 & 89 \\
Ofla & Highland & 25,378 & 111 \\
Total & & 72,326 & 318 \\
\hline
\end{tabular}

a Source: Central Statistics Agency of Ethiopia (CSA, 2007)

\section{Method of data collection}

Both qualitative and quantitative data were collected for this study. Qualitative data were obtained using in-depth interviews that included group discussants and key informants, drawn from livestock experts, extension workers, district officials, and local leaders. Using household survey, primary data were obtained from the sampled respondents using semi-structured questionnaire (Additional file 1). The semi-structured questionnaire (close-ended multiple choice and open-ended type questions) was used to generate quantitative data on household characteristics, socio-economic parameters, marketing, institutional, and educational features of the sheep and goats farmers through interview, and sample household heads were the unit of analysis.

\section{Data analysis}

Data were analyzed using STATA software version 11. Descriptive statistical tools like mean, percentage, minimum and maximum were employed to analyze, describe and summarize respondents' socioeconomic, cultural, environmental and climate related variables.

\section{Econometric analysis}

Multivariate probit model was employed to investigate the factors that determine the choice of adaptation strategies. OLS (Ordinary Least Square) model was also applied to demonstrate the effect of each adaptation strategy on income generated from the sales of sheep and goats.

Farmers' adaptation activities to respond to climate change can be influenced by various factors, including household income, market, culture, and institutions. This study analyzed various factors that influence the producers of sheep and goats in choosing context-based adaptation methods to cope climate change effects. Farmers rearing sheep and goats can carry out many adaptation actions as long as their activity provides them a certain level of benefits. The adaptation choice that each farmer has to make can also be based on the resources they possess.

Identification of each factor that influences the behavior of farmers is very important. Although the multinomial probit can be used to measure the set of adaptation choices being applied by sheep and goats producers, its limitation is difficult to make interpretations for the simultaneous influences of explanatory variables on each outcome variable (endogeneity problem cannot be addressed using multinomial probit). This is because the local adaptive choices practiced by the farmers are either substitutive or supplementary of one another. Even if the univariate probit model is possible to estimate the 
adaptive choices of farmers on the available alternative measures, it is prone to bias due to neglecting the common factors that are not observable and unmeasured. In this case, a separate measurement using probit model never shows the relationships among various adaptation choices.

The multivariate probit model is appropriate to handle such measurement problems. It also allows the user to produce more than one equation with correlated disturbances, thereby enabling examination of the relationships among the outcome variables. During estimation, the adaptation choices of dependent variables in the multivariate model do not have negative values and hence, the error terms could be correlated to several predictors. Unlike in the ordinary least square method (OLS), the assumption of mean zero is senseless in the use of a multivariate model. By addressing the correlations of the error terms among unobserved adaptation choices, the multivariate model ensures statistical efficiency in the estimations of available choices as shown below (Lin et al. 2005).

$$
\begin{aligned}
& Y_{i}=1 \quad \text { if } X^{\prime} \beta_{i}+\varepsilon_{i}>0 \\
& Y_{i}=0 \quad \text { if } X^{\prime} \beta_{i}+\varepsilon_{i} \leq 0, \quad i=1,2,3, \ldots, n
\end{aligned}
$$

where $Y_{i}$ is a vector of dependent variables (each serves as adaptation choice), $X^{\prime}$ is a vector of explanatory variables, $\beta_{i}$ is a vector of coefficients, $\varepsilon_{i}$ is a random error term and $n$ is number of observations with zero means and unitary variance.

Exploring determinants of adaptation to cope with climate change risk alone will not provide full information. Thus, it is critical to investigate advantage of the strategies farmers consider fitting to adapt climate change. Accordingly, the study tried to show the effect of adaptation practices, currently used by sheep and goats farmers, on farmers' livelihoods. Hence, income from the sale of sheep and goats was used as a dependent variable.

In the first instance, Heckman model was regressed to examine the effect of each adaptation strategy on income from the sale of sheep and goat production. Due to the unobservable nature of the dependent variable for some observations, the outcome variable was not observed for all respondents, but selection bias was not the problem. Because an inverse Miller ratio was not significant in a Heckman two-stage estimation method, implying that applying the OLS model is appropriate.

Income from the sale of sheep and goats is given by the equation as:

$$
Y_{i}=X^{\prime} \beta_{i}+\varepsilon_{i}>0
$$

where $Y_{i}$ is the individual household's income obtained from sales of sheep and goats, $\mathrm{Xi}$ is a vector of observable factors that affect the level of income from sheep and goats market and $\varepsilon_{i}$ is the error term.

\section{Dependent and independent variables}

\section{Dependent variables}

The dependent variables included in the analysis are the adaptation strategies adopted by sheep and goat farmers and income from the sale of sheep and goats. The most common adaptation strategies identified during focus group discussion and key informant 
interviews were feeding the sheep and goats at home (home feeding), provision of shade during cold and warm season, having crossbred animals and marketing during shocks.

\section{Independent variables}

Independent variables include in the analysis are socio-economic, institutional, and environmental factors. Specifically, desired variables were sex and age of the household head, household income, marital status, access to credit, educational status of the head, family size, farm size, agro-ecological zones, herd size, access to credit, access to extension service, access to information on climate change, farming experience, number of household in one village, and distance to main market. Independent variables are clearly mentioned in Table 2.

\section{Results and discussion}

\section{Socio-economic and institutional characteristics of the households}

Socio-economic and institutional characteristics of the households are shown in Table 3. Three hundred eighteen households in three agro-ecological settings were enrolled in this study. Two hundred forty five $(77.0 \%)$ were male-headed households; whereas the remaining 73 (23.0 \%) were female-headed. Household heads had a mean age of 43 years,

Table 2 Description of variables included in the analysis

\begin{tabular}{|c|c|c|c|c|}
\hline Independent variables & Variable type & Variable measurement & Mean & SD \\
\hline Sex of the head & Dummy & 1 if male, 0 otherwise & 0.773 & 0.421 \\
\hline Age of the head & Continuous & Year & 43.405 & 9.855 \\
\hline Marital status & Dummy & 1 if married, 0 otherwise & 0.789 & 0.408 \\
\hline Family size & Continuous & Number & 5.405 & 1.782 \\
\hline Land size & Continuous & Hectare & 0.529 & 0.425 \\
\hline Herd size & Continuous & Total Livestock Unit (TLU) & 5.532 & 4.200 \\
\hline Access to info. & Dummy & 1 if there is access, 0 otherwise & 0.984 & 0.124 \\
\hline Year of production & Continuous & Number & 11.639 & 8.203 \\
\hline $\begin{array}{l}\text { Number of households } \\
\text { in one village }\end{array}$ & Continuous & Number & 487.9 & 220.14 \\
\hline Extension assistance & Dummy & $\begin{array}{l}1 \text { if household gets ext.assi. } \\
0 \text { otherwise }\end{array}$ & 0.99 & 0.096 \\
\hline Credit access & Dummy & 1 if there is access, 0 otherwise & 0.927 & 0.259 \\
\hline Distance to mkt & Continuous & $\mathrm{Km}$ & 4.1173 & 5.902 \\
\hline High land & Dummy & $\begin{array}{l}1 \text { if respondent from highland, } \\
0 \text { otherwise }\end{array}$ & 0.349 & 0.477 \\
\hline Low land & Dummy & $\begin{array}{l}1 \text { if respondent from lowland, } \\
0 \text { otherwise }\end{array}$ & 0.371 & 0.483 \\
\hline Mid land(base category) & Dummy & $\begin{array}{l}1 \text { if respondent from midland, } \\
0 \text { otherwise }\end{array}$ & 0.279 & 0.449 \\
\hline Monthly consumption & Continuous & Birr (1 USD = 19.73 Birr $)$ & 1124.1 & 929.64 \\
\hline Edu1(base category) & Dummy & 1 if illiterate, 0 otherwise & 0.345 & 0.476 \\
\hline Edu2 & Dummy & $\begin{array}{l}1 \text { if informally literate (read and write), } \\
0 \text { otherwise }\end{array}$ & 0.154 & 0.361 \\
\hline Edu3 & Dummy & $\begin{array}{l}1 \text { if primary school completed, } \\
0 \text { otherwise }\end{array}$ & 0.443 & 0.497 \\
\hline Edu4 & Dummy & $\begin{array}{l}1 \text { if secondary school completed, } \\
0 \text { otherwise }\end{array}$ & 0.047 & 0.212 \\
\hline Edu5 & Dummy & 1 if above secondary, 0 otherwise & 0.009 & 0.096 \\
\hline
\end{tabular}


and this ranged between 21 and 72 years. Education has an important effect on the choice of adaptation strategies. This is because educated individuals are expected to be exposed to better information about climate change; thereby he/she chooses compatible adaptation strategies. As shown in Table 3, 126 (34.6\%) were illiterate (at least they cannot read and write) and 18 (5.6\%) respondents completed secondary school and above. A significant number of the households ( $92.8 \%$ ) had access to credit, and over $60 \%$ participated in off-farm activities. Particularly, the number of off farm participants in the midland agro ecological zone (Alaje district) was found to have the smallest share as compare to the two agro-ecological zones (Table 3). As confirmed by key informants and group discussants, most farmers in Alaje district have fertile farmlands and better opportunity to grow crops and vegetables using irrigation practices. This allowed farmers to stay in own farming instead of pursuing off farming. Income at household level is also an important variable, but under reporting of income by respondents is also expected. Because people are less willing to reveal their income compared to their expenditure. Thus, to control this variable expenditure was used as a proxy for income in this study.

\section{Farmers' perceptions on climate change}

Farmers were asked about their perception whether climate is changing or not over the last 10 years. Most of the respondents $(96.0 \%)$ perceived that climate change is indeed occurring. Among climate change indicators, temperature and rainfall were considered as parameters for the analysis. The responses from respondents in relation to changes in temperature and rainfall across three agro-ecological zones are depicted in Figs. 1 and 2, respectively. Most of the respondents acknowledged that there is rise in temperature and decline in rainfall amount.

Table 3 Socio-economic and institutional characteristics of sheep and goat farmers

\begin{tabular}{lcccr}
\hline Variables & \multicolumn{2}{l}{ Agro-ecological setting } & Total \\
\cline { 2 - 4 } & Highland & Midland & Lowland & \\
\hline Sex head & & & & \\
Male (1) & $54(48.6)$ & $82(92.1)$ & $109(92.4)$ & $245(77.0)$ \\
Female (0) & $57(51.4)$ & $7(7.9)$ & $9(7.6)$ & $73(23.0)$ \\
Education & & & & \\
Illiterate (1) & $53(47.7)$ & $21(23.6)$ & $36(30.5)$ & $126(39.6)$ \\
Informally literate (2) & $29(26.1)$ & $16(17.9)$ & $4(3.4)$ & $49(15.4)$ \\
Primary school (3) & $22(19.8)$ & $48(53.9)$ & $71(60.1)$ & $141(44.3)$ \\
Secondary school (4) & $5(4.6)$ & $4(4.5)$ & $6(5.0)$ & $15(4.7)$ \\
Above Secondary school (5) & $2(1.8)$ & $0(0)$ & $1(0.84)$ & $3(0.9)$ \\
Access to credit & & & & $295(92.8)$ \\
Yes (1) & $98(88.2)$ & $86(96.6)$ & $111(94.1)$ & $23(7.2)$ \\
No (0) & $13(11.7)$ & $3(3.4)$ & $7(5.9)$ & $189(59.4)$ \\
Off-farm participation & & & & $129(40.6)$ \\
Yes (1) & $74(66.7)$ & $18(20.2)$ & $97(82.2)$ & $21(17.8)$ \\
No (0) & $37(33.3)$ & $71(79.8)$ & & \\
\hline
\end{tabular}




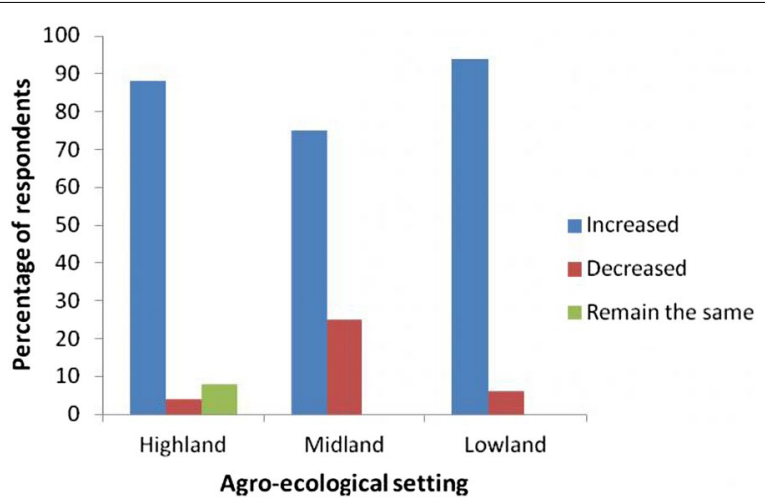

Fig. 1 Farmers'response about climate change through change in temperature. It indicates the change in temperature due to climate change as reported by farmers' from three different agro-ecological settings of Southern and Central Tigray Zones

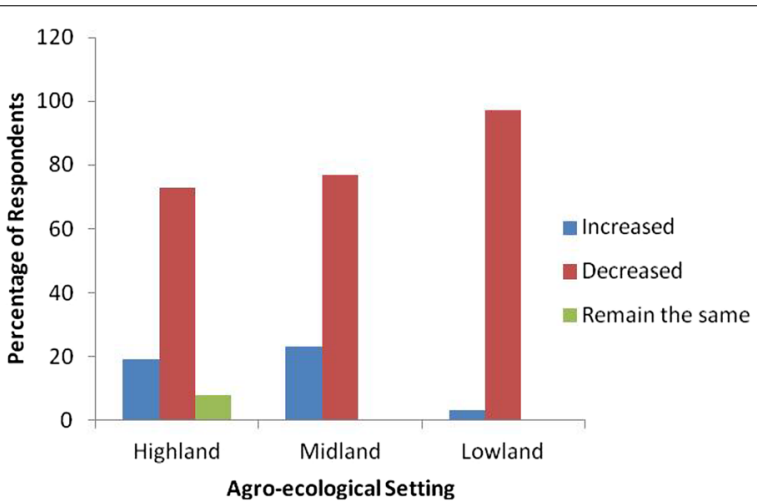

Fig. 2 Farmers' response about climate change through change in rainfall amount. It indicates the change in rainfall amount due to climate change as reported by farmers' from three different agro-ecological settings of Southern and Central Tigray Zones

Eighty-eight percent and $73 \%$ of the respondents from the high-land agro-ecological zone observed that the temperature was rising and the rainfall level was declining in the last 10 years, respectively. A few respondents $(8 \%)$ in this agro-ecological zone had reported that there is no change both in temperature and rainfall amount. Similar to the high-land agro-ecological zone, respondents in mid land consisted large proportion in reporting rise in temperature $(75 \%)$ and decline in rainfall amount $(77 \%)$. In the same line, in lowland agro-ecological zone, respondents perceived that the temperature was increasing (94\%) whereas the rainfall amount was declining (97\%) over the last 10 years.

Farmers' response towards perception on climate change is consistent with other studies. Studies conducted in Ethiopia by Deressa et al. (2008) and Mengestu (2011) reported that the temperature is rising and rainfall amount is decreasing due to climate change. Studies conducted in other African countries like South Africa (Mandleni and Anim 2011a), Ghana (Kemausuor et al. 2011), and Nigeria (Apata, 2011) also documented similar findings with this study on farmers' perception about climate change. 


\section{Adaptation strategies to climate change pursued by farmers}

The distribution of adaptation strategies used by sheep and goat farmers in response to climate change is shown in Table 4. The most common adaptation strategy is marketing during shock. A total of 307 (96.5 \%) farmers were found to use marketing during shock as a climate change adaptation strategy. This practice enabled farmers to sell their sheep and goats during extreme weather events because animals were unable to resist long dry periods due to deficiency of feed and water. However, this has its own drawback, as animals will not be fetching good prices; ideally it is recommended that farmers participate in the normal time market. The second most commonly used adaptation strategy by the farmers is home feeding. Out of the total respondents, 285 (89.6\%) of them practiced this adaptation strategy. As reported by key informants and group discussants, this was mainly because of the introduction of area enclosures in almost all communal lands of villages by which farmers were obliged to feed their animals at home. As shown in Table 4, provision of shade during extreme weather events, hot and cold season, was the least practiced adaptation option to cope with climate change effects. This may be because of incidental expenses related to building houses and preparation of bedding that require to incur the high cost of materials and skilled human capital.

The distribution of adaptation strategies by agro-ecological settings is also presented in Table 4. In all the three agro-ecological settings, marketing during climate shock is the most commonly used option. On the other side, providing shade during hot and cold season is the least practiced adaptation practice in all the study sites. The table clearly shows that farmers exercising provision of shade in lowland agro-ecological zones consisted of small proportion (22.8 \%) as compared to those of in the mid-land (54 \%) and highland $(52.7 \%)$ regions. Since goats are relatively tolerant of high temperature and are better able to survive in the lowland, farmers in this area may be reluctant to engage in putting up shade, compared to those in the midland and highland areas who mainly rearing sheep.

\section{Determinants of choice of adaptation practices by sheep and goat farmers}

Prior to the main estimation, pre-estimation, tests were undertaken. Multicollinearity was tested using Variance Inflation Factor (VIF) and Contingent Coefficient (CC) for continuous and discrete explanatory variables, respectively (Additional file 2). VIF for all continuous variables were $<10$, and $C C$ for all discrete variables was $<0.75$, which indicate multicollinearity is not a serious problem in the model estimation (Gujarati 2004; Rabe-Hesketh and Everitt 2004). The result of multivariate probit model is presented in

Table 4 Distribution of adaptation options used by sheep and goats farmers

\begin{tabular}{lcccr}
\hline Adaptation options & \multicolumn{2}{l}{ Agro-ecological settings } & Total \\
\cline { 2 - 4 } & Low-land & Mid-land & High-land & \\
\hline Provision of shade & $27(22.8)$ & $48(54.0)$ & $57(52.7)$ & $132(41.5)$ \\
Home feeding & $103(87.2)$ & $86(96.6)$ & $96(88.8)$ & $285(89.6)$ \\
Use of crossbred animals & $63(53.3)$ & $43(48.3)$ & $67(62.0)$ & $173(54.4)$ \\
Marketing during shock & $117(99.0)$ & $85(95.5)$ & $105(97.0)$ & $307(96.5)$ \\
\hline
\end{tabular}

Numbers in parenthesis indicate percentage 
Table 5 Results of multivariate probit model for determinants of adaptation choices

\begin{tabular}{|c|c|c|c|c|c|c|c|c|}
\hline \multirow{3}{*}{$\begin{array}{l}\text { Independent } \\
\text { variables }\end{array}$} & \multicolumn{8}{|c|}{ Dependent variables } \\
\hline & \multicolumn{2}{|c|}{ Home feeding } & \multicolumn{2}{|l|}{ Crossbred } & \multicolumn{2}{|l|}{ Marketing } & \multicolumn{2}{|l|}{ Shade } \\
\hline & Coeff. & $P$ value & Coeff. & $P$ value & Coeff. & $P$ value & Coeff. & $P$ value \\
\hline Sex & $-0.8021^{*}$ & 0.097 & -0.2438 & 0.450 & -0.1195 & 0.848 & -0.0901 & 0.772 \\
\hline Age & 0.0160 & 0.280 & -0.0142 & 0.159 & 0.0318 & 0.325 & $-0.0209^{*}$ & 0.053 \\
\hline Marital status & $0.8064^{*}$ & 0.068 & $0.5333^{*}$ & 0.076 & 0.2756 & 0.640 & 0.2647 & 0.368 \\
\hline Family size & 0.0020 & 0.978 & 0.0509 & 0.356 & -0.0554 & 0.681 & $0.1084^{*}$ & 0.052 \\
\hline Land size & 0.4527 & 0.283 & 0.0140 & 0.944 & 0.1522 & 0.849 & -0.1722 & 0.492 \\
\hline Herd size & 0.0008 & 0.979 & 0.0439 & $0.100^{*}$ & 0.0459 & 0.514 & 0.0067 & 0.780 \\
\hline Access to info. & $1.7645^{* *}$ & 0.013 & $1.7009^{* *}$ & 0.027 & $3.1643^{* * *}$ & 0.000 & 0.9316 & 0.184 \\
\hline Year of production & -0.0267 & 0.158 & $0.0310^{* *}$ & 0.014 & 0.0048 & 0.887 & $0.0323^{* * *}$ & 0.009 \\
\hline $\begin{array}{l}\text { No. households in } \\
\text { one village }\end{array}$ & 0.0006 & 0.340 & $-0.0015^{* * *}$ & 0.001 & 0.0007 & 0.428 & $-0.0010^{* *}$ & 0.031 \\
\hline Credit access & -0.4864 & 0.418 & -0.4548 & 0.211 & -3.6721 & 0.988 & -0.0986 & 0.792 \\
\hline Distance to mkt & $-0.0398^{* * *}$ & 0.007 & 0.0020 & 0.879 & 0.0180 & 0.739 & 0.0116 & 0.373 \\
\hline Highland & $-1.1812^{* *}$ & 0.017 & $1.7441^{* * *}$ & 0.000 & 0.6275 & 0.380 & $0.6206^{* *}$ & 0.043 \\
\hline Lowland & $-1.4700^{* * *}$ & 0.000 & 0.0101 & 0.962 & 0.6501 & 0.270 & $-0.7218^{* * *}$ & 0.001 \\
\hline $\begin{array}{l}\text { Monthly } \\
\text { consumption }\end{array}$ & $-0.4818^{* *}$ & 0.023 & $-0.4502^{* * *}$ & 0.001 & -0.2690 & 0.381 & 0.0518 & 0.712 \\
\hline Edu2 & 0.2731 & 0.455 & -0.0194 & 0.940 & 0.1190 & 0.823 & 0.0128 & 0.959 \\
\hline Edu3 & 0.0127 & 0.966 & -0.0184 & 0.932 & 0.0724 & 0.881 & 0.0262 & 0.901 \\
\hline Edu4 & -0.3680 & 0.470 & -0.3914 & 0.355 & 0.7316 & 0.562 & -0.0210 & 0.962 \\
\hline Edu5 & 4.2013 & 0.993 & 5.0015 & 0.989 & 3.1296 & 0.996 & 5.2491 & 0.987 \\
\hline
\end{tabular}

$*^{* * *}$ and ${ }^{* * *}$ are at 10,5 and $1 \%$ level significant respectively

Table 5. Although education was presumed to have an important effect on the choice of adaptation strategies while education was insignificant in adopting adaptation strategies (Table 5). This could be the reason that educated individuals in the study area are engaged in searching off farm job. Therefore, they are less likely to participate in farming practice in which adaptation is required. Only those variables whose coefficients are statistically significant at 1 and $5 \%$ probability levels were discussed.

\section{Access to information}

This variable represents sources of information required to make the decision to adapt to climate change such as TV, radio, magazine, newspaper, personal observation, development agents, etc. An individual exposed to climate information is more likely to take an immediate action to cope with risks related to climate change. The model result shows that access to information has positive and significant impact on home feeding, use of crossbred animals, and marketing during shock (Table 5). Many studies also reported strong positive relationship between access to information and adaptation (Deressa et al. 2008; Asayehegn 2012; Di Faclo et al. 2011; Tazeze et al. 2012; Balew et al. 2014).

\section{Farming experience}

Farming experience in the rearing of sheep and goats was one of the explanatory variables thought to affect adaptation strategies to climate change. Farming experience 
positively and significantly affects the choice of having crossbred animals and shading adaptation practices. This effect suggests that farmers with longer periods of farming experience were more likely to understand climate change and its negative consequences and are more willing to respond to climate change effects through implementing different adaptation practices. In addition, farmers with experience observe changes over time and compare such changes with the current climatic conditions, which enable them to respond to climate change. This result is consistent with other numerous studies (Dhakal et al. 2013; Mabe et al. 2014; Obayelu et al. 2014).

\section{Number of households in one village}

The coefficient of this variable has a significant and negative relationship with the likelihood of choosing adaptation measures; crossbred and provision of shade. In the case of shading as adaptation practice, increase in number households in one village may result in shortage of land. Thus, farmers cannot have enough places to prepare shade for their animals.

\section{Distance to market ( $\mathrm{km})$}

The model result shows that as the distance to market increases, the probability of choosing the adaptation practice to feed the animals at home decreases. The analysis shows statistical significance at the $5 \%$ probability level. Households far from the main market may not get supplementary feed easily and prefer to let the animals graze. Market was one means of exchanging information with other farmers, and it provides an opportunity for sharing experiences on adaptation to climate change. Similar findings were also reported by (Hassan and Nhemachena 2008; Tazeze et al. 2012; Balew et al. 2014).

\section{Highland agro-ecological zone}

As expected, different farmers live in different agro-ecological settings, take up different adaptation options (Deressa et al. 2008; Tazeze et al. 2012). This explanatory variable was found to have a significant effect on the provision of shade, having crossbred animals, and home feeding. The model showed a positive relationship of adoption to having crossbred animals and shading adaptation practices, but not for the home feeding practice. This implies that being a resident in highland agro-ecological zone, as compared to that of midland, increases the probability of having crossbred animals and implementing shading practice; whereas it reduces the probability of using home feeding adaptation practice.

\section{Lowland agro-ecological zone}

Farmers living in lowland agro-ecological zone are less likely to practice shading management and to feed their sheep and goats at home. This explanatory variable affects the probability of choosing home feeding and provision of shade as an adaptation strategy at $1 \%$ significance level. This could be the reason that goats are resistant to dry season are dominant in lowland agro-ecological zone. 
Table 6 Results of OLS model for determinants of income from the sales of sheep and goat

\begin{tabular}{lcc}
\hline Independent variables & Coefficient & P value \\
\hline Home_feeding & $1877.711^{* * *}$ & 0.007 \\
Cross bred_animal & $1182.326^{* * *}$ & 0.006 \\
Shade & 1182.326 & 0.142 \\
Sex & 688.3208 & 0.289 \\
Age & 22.0632 & 0.303 \\
Farm size & -166.2574 & 0.169 \\
Land_size & 91.93275 & 0.823 \\
Herd size & $498.7345^{* * *}$ & 0.000 \\
Farm association & $-1982.854^{* * *}$ & 0.001 \\
Extension assistance & 1556.691 & 0.404 \\
Credit acess & $1841.97^{* *}$ & 0.040 \\
mkt_km & 4.680807 & 0.870 \\
High_land & 179.9796 & 0.801 \\
Low_land & $-1224.172^{* *}$ & 0.044 \\
Monthly consumption & 352.5096 & 0.320 \\
edu2 & -482.141 & 0.424 \\
edu3 & -480.5437 & 0.314 \\
edu4 & -629.2862 & 0.518 \\
edu5 & -2291.116 & 0.412 \\
_cons & -3748.746 & 0.233 \\
\hline **and*** are at 5 and 1 \% significance level respectively & &
\end{tabular}

\section{Monthly consumption (income)}

The study found that household income has a negative and significant impact on the choice of adaptation options having crossbred animals and home feeding. This may be because higher income farmers may be less risk averse, and as a result, they may not pay for adaptation measures against climate change. A study by Mandleni and Anim (2011b) has shown that non-farm income decreased the likelihood of adaptation measures. On the other hand, contradicting findings were also reported in studies by Deressa et al. (2008), Sahua and Mishrab (2013), Getachew et al. (2014), Mabe et al. (2014), where household income is positively associated with adaptation measures.

\section{Do adaptation strategies have contribution on income from sheep and goat sales?}

The result (Table 6) shows that annual income from the sale of sheep and goats was positively related to farmer's adaptation practices. Home feeding and having crossbred animals affect the income from the sale of sheep and goats at $1 \%$ significance level. Practicing home feeding and having crossbred animals increased the revenue from the trade of sheep and goat by 1877 and 1182 birr $^{1}$ respectively. Other variables such as herd size and access to credit have positive and significant effects on the income. As the herd size increased, animals offered to the market also increased, which results in additional revenues. As the herd size increased by one unit, the sale of sheep and goats increased by 498 birr. Access to credit also has a positive influence on the sales of sheep and goats.

\footnotetext{
${ }^{1}$ 1USD was equivalent to 19.73 Ethiopian Birr when the data for this study was collected in July 2014
} 
This may be because access to credit reduces the financial burden to purchase animal feed and other farm inputs, which boost their agricultural production overall.

Farming in the lowland agro-ecological setting and involvement in farm associations affects the outcome variable negatively, though the latter was expected to affect the outcome variable positively. This is because, as key informants interview reveal, farm associations build social-capital that supports farmers in providing different technical guidance and advice about agricultural production and overall rural development. Longdry season is one of the features of lowland agro-ecological zone as compared to other agro-ecological zones, which affects animal feed to be scarce and decreases its nutritive value. Hence, farmers in lowland agro-ecological settings are less competitive in the market of sheep and goat, which indicates that revenue from the sales of sheep and goats, is quite low. Assuming other factors constant, living as a farmer in lowland agroecology and involved in farm association decreases the sale of sheep and goats by 1224 and 1982 birr, respectively.

\section{Conclusion and recommendations}

Findings from Ofla, Alaje and Kola-Tembien suggest that more than $96 \%$ of local farmers were able to perceive the adverse effects of climate change. They apparently noticed that climate change drastically reduced the amount of rainfall, which evidently exhibited in terms of occurrence of frequent drought with its immediate consequences on loss of their livestock and crop productivity. In the due course of responding the negative effects of climate change, producers of small ruminants continued to pursue multiple adaptation methods. Field -based assessments on indicators of multiple adaptation choices were conducted and the estimated results indicated that nearly $96 \%$ of the farmers were found to use marketing. During drought periods, farmers used to sell their livestock because of fear of lack of natural grazing and animal feed.

The findings from multivariate probit model revealed that the farmers' choice of adaptation strategies were statistically and significantly affected by factors such as access to information, farming experience, distance to main market, household income, agroecological zone and number of households in a village. Moreover, results from OLS model revealed that home feeding strategy (the strategy of keeping and feeding animals at home) was recently getting adopted by farmers. As reasoned out by key informants, farmers chose to pursue zero-grazing because they have already experienced that the use of communal water sources and free grazing were the sources of communicable diseases. It was also found that the strategy to access to cross bred animals was an important factor, which positively and significantly associated to the household income level.

However, the emphasis of this study was mainly to identify the possible adaptation choices applied by small ruminant producers. Environmental effects of producing small ruminant animals are beyond the scope of this study. Thus, we suggest further investigation on issues of rangeland capacity to accommodate herds of sheep and goats sustainability. Considering the above findings and shortfalls, it is suggested to design early warning policy systems that aim to make the locals aware of future climate variability and potential shocks so that they can take proactive steps to use varying approaches that best fit to different agro-climatic conditions. 


\section{Additional files}

Additional file 1. Questionnaire

Additional file 2. Variance Inflation Factor (VIF) and Contingent Coefficient (CC) for continuous and discrete explanatory variables.

\section{Authors' contributions}

FBF was the principal investigator who designed and conducted the survey, analyzed the data and wrote the manuscript. MB, GG and DH contributed to the survey design and revised the draft manuscript. All authors'read and approved the final manuscript.

\section{Author details}

1 Department of Natural Resource Economics and Management, College of Dryland Agriculture and Natural Resource, Mekelle University, P.O. Box 231, Mekelle, Ethiopia. ${ }^{2}$ MARIL Research and Development, P.O. Box 90112, Addis Ababa, Ethiopia. ${ }^{3}$ Department of Agricultural and Resource Economics, Colorado State University, Fort Collils, CO 80523-1172, USA.

\section{Acknowledgements}

The authors would like to thank Feed the Future Innovation Lab for Collaborative Research on Adapting Livestock Systems to Climate Change for funding this study. We are also thankful for administrative leaders, respondents and enumerators for their cooperation during group discussion and in providing helpful information.

\section{Competing interests}

The authors declare that they have no competing interests.

Ethics, consent and permissions

Written informed consent was obtained from all study participants.

Received: 5 September 2015 Accepted: 11 August 2016

Published online: 01 October 2016

\section{References}

Adger WN, Huq S, Brown K, Conway D, Hulme M (2003) Adaptation to climate change in the developing world. Prog Dev Stud 3:179-195

Alam MM, Hashem MA, Rahman MM, Hossain MM, Haque MR, Sobhan Z, Islam MS (2011) Effect of heat stress on behavior, physiological and blood parameters of goat. Progress Agric 22:37-45

Al-Haidary AA (2004) Physiological responses of Naimey sheep to heat stress challenge under semi-arid environments. Int J Agric Biol 6(2):307-309

Amankwah K, Klerkx L, Oosting SJ, Dawson OS, Zijpp AJ, Millar D (2012) Diagnosis constraints to market participation of small ruminant producers in Northern Ghana: an innovation systems analysis. Wagening J Life Sci 60-63:37-47

Apata TG (2011) Factors influencing the perception and choice of adaptation measures to climate change among farmers in Nigeria: evidence from farm households in Southwest Nigeria. Environ Econ 2(4):74-83

Asayehegn K (2012) Farmers' perception on climate change adaptation strategies: a case study from the irrigation schemes of Central Tigray Regional State, Ethiopia. Erud J Microbiol Biodivers 1(1):1-6

Ayele G, Jabbar MA, Teklewold H, Mulugeta E, Kebede G (2008) Seasonal and inter-market differences in prices of small ruminants in Ethiopia. J Food prod Mark 12:59-77

Balew S, Agwata J, Anyango S (2014) Determinants of adoption choices of climate change adaptation strategies in crop production by small scale farmers in some regions of Central Ethiopia. J Nat Sci Res 4(4):78-93

Central Statistics Authority (2007) Summary statistics and statistical report of population and housing census. Addis Ababa, Ethiopia

Chand MB, Upadhyay BP, Maskey R (2012) Biogas option for mitigating and adaptation of climate change. Ren Sym Comp 1:5-9

Deressa TT (2007) Measuring the economic impact of climate change on Ethiopian Agriculture: Ricardian approach. In: World Bank Policy Research Paper No. 4342. World Bank, Washington, DC

Deressa T, Hassan RM, Alemu T, Yesuf M, Ringler C (2008) Analyzing the determinants of farmers' choice of adaptation methods and perceptions of climate change in the Nile Basin of Ethiopia. In: International food policy research institute (IFPRI), Discussion Paper No. 00798. IFPRI, Washington, DC

Dhakal CK, Regmi PP, Dhakal IP, Khanal B, Bhatta UK (2013) Determinants of livestock holders' adaptive capacity to climate change in Gandaki River Basin, Nepal. In: Proceedings book of ICEFMO, Malaysia, handbook on the economic, finance and management outlooks, pp 255-263

Di Faclo S, Yesuf M, Kohlin G, Ringler C (2011) Estimating the impacts of climate change on agriculture in low-income countries: household level evidence from the Nile Basin, Ethiopia. Environ Resour Econ 52:457-478

Dick Cl, Ghanem AM, Hamaadeh SK (2008) Adaptation strategies of small ruminants production systems to environmental constraints of semi-arid areas of Lebanon. In: 8th European IFSA symposium, 6-10 July 2008, Clermont-Ferrand (France) WS 3: adaptive farming systems, pp 515-517

FDRE (2011) Ethiopia's climate-resilient green economy green economy strategy. Addis Ababa, Ethiopia 
Gebreegziabher Z, Stage J, Mekonnen A (2011) Climate change and the Ethiopian economy: a computable general equilibrium analysis. In: RFF discussion paper EfD 11-09; Ressources For the Future, Washington

Getachew S, Tilahun T, Teshager M (2014) Determinants of agro-pastoralist climate change adaptation strategies: case of Rayitu Woredas, Oromiya Region, Ethiopia. Res J Environ Sci 8(6):300-317

Gujarati DN (2004) Basic econometrics, 4th edn. McGraw Hill Companies, New York

Hailu Y (2014) Ectoparasitism: threat to Ethiopian small ruminant population and tanning industry. J Vet Med Ani Heal 6:25-33

Hassan R, Nhemachena C (2008) Determinants of African farmers'strategies for adapting to climate change: multinomial choice analysis. Afr J Agric Res Econ 2(1):83-104

Henry BK, Charmley E, Eckard R, Gaughan JB, Hegarty R (2012) Livestock production in a changing climate: adaptation and mitigation research in Australia. J Crop Past Sci 63:191-202

Kandemir C, Koşum N, Taşkin T (2013) Effects of heat stress on physiological traits in sheep. Maced J Anim Sci 3(1):25-29

Kemausuor F, Dwamena E, Bart-Plange A, Kyei-Baffour N (2011) Farmers' perception of climate change in the Ejura-Sekyedumase district of Ghana. J Agric Biol Sci 6:26-37

Legesse G, Abebe G, Schultze MS, Vallezarate A (2008) Small ruminant production in two mixed-farming systems of southern Ethiopia: status and prospects for improvement. Exp Agric 44:399-412

Lin CTJ, Jensen KL, Yen ST (2005) Awareness of food-borne pathogens among US consumers. Food Qual Prefer 16:401-412

Mabe FN, Sienso G, Donkoh S (2014) Determinants of choice of climate change adaptation strategies in northern Ghana. Res Appl Econ 6(4):75-94

Mandleni B, Anim FDK (2011a) Perceptions of cattle and sheep farmers on climate change and adaptation in the eastern cape province of south africa. J Hum Ecol 34(2):107-112

Mandleni B, Anim FDK (2011b) Climate change awareness and decision on adaptation measures by livestock farmers in South Africa. J Agric Sci 3(3):258-268

Mengestu DK (2011) Farmers' perception and knowledge of climate change and their coping strategies to the related hazards: case study From Adiha, Central Tigray, Ethiopia. J Agric Sci 2:138-145

Musara JP, Chimvuramahwe J, Munyati V, Chivheya R, Mwadzingeni L (2013) Why not commercial goat production? Exploring Rural Communities' Preference for livestock enterprise: case of matsai communal area, Zimbabwe. J Agric Res Dev 3:02-034

Naqvi SMK, Sejian V (2011) Global climate change: role of livestock. Asian J Agric Sci 3:19-25

Nelson GC, Rosegrant MW, Koo J, Robertson R, Sulser T, Zhu T, Ringler C, Msangi S, Palazzo A, Batka M, Magalhaes M, Valmonte-Santos R, Ewing M, Lee D (2009) Climate change: impact on agriculture and costs of adaptation. International Food Policy Research Institute, Washington, DC

Obayelu OA, Adepoju AO, Idowu T (2014) Factors influencing farmers' choices of adaptation to climate change In Ekiti State, Nigeria. J Agric Environ Int Dev 108(1):3-16

Oseni S, Bebe O (2010) Climate change, genetics of adaptation and livestock production in low-input systems. In: 2nd international conference: climate, sustainability and development in semi-arid regions, August 16-20, Fortaleza Ceará, Brazil

Panin A (2000) A comparative economic analysis of smallholder cattle and small ruminant production systems in Botswana. Trop Anim Health Prod 32:189-196

Parry ML, Rosenzweig C, Iglesias A, Livermore M, Fischer G (2004) Effects of climate change on global food production under SRES emission and socio-economic scenarios. J Glob Environ Change 14:53-67

Rabe-Hesketh S, Everitt B (2004) A handbook of statistical analyses using stata, 3rd edn. A CRC Press Company, New York

Sahoo A, Kumar D, Naqvi SMK (eds) (2013) Climate resilient small ruminant production. In: National Initiative on Climate Resilient Agriculture (NICRA), Central Sheep and Wool Research Institute, Izatnagar, India, pp 1-106

Sahua NC, Mishrab D (2013) Analysis of perception and adaptability strategies of the farmers to climate change in Odisha, India. APCBEE Proc 5:123-127

Sejian V (2013) Climate change: impact on production and reproduction, adaptation mechanisms and mitigation strategies in small ruminants: a review. Indian J Small Rumin 19(1):1-21

Sevi A, Casamassima D, Pulina G, Pazzona A (2007) Factors of welfare reduction in dairy sheep and goats. Ital J Anim Sci 8(Suppl. 1):81-101

Singh SK, Meena HR, Kolekar DV, Singh YP (2012) Climate change impacts on livestock and adaptation strategies to sustain livestock production. J Vet Adv 2:407-412

Taruvinga A, Muchenje V, Mushunje A (2013) Climate change impacts and adaptations on small-scale livestock production. Int J Dev Sust 2:664-685

Tazeze A, Haji J, Ketema M (2012) Climate change adaptation strategies of smallholder farmers: the case of Babilie district, East Harerghe Zone of Oromia regional state of Ethiopia. J Econ Sustain Dev 3(14):1-12

Tologbonse EB, Iyiola-Tunji AO, Issa FO, Jaliya MM, Dauda CK, Adedokun IK, Bi Okoro (2011) Assessment of climate change adaptive strategies in small ruminant production in rural Nigeria. J Agric Ext 15(2):31-39

Tubiello F (2012) Climate change adaptation and mitigation: challenges and opportunities in the food sector. Natural resources management and environment department, FAO, Rome. Prepared for the high-level conference on world food security: the challenges of climate change and bioenergy, Rome, 3-5 June 2008

You GJ, Ringler C (2011) Climate change impacts in Ethiopia: hydro-economic modeling projections. In: IFPRI research brief, pp 15-19 